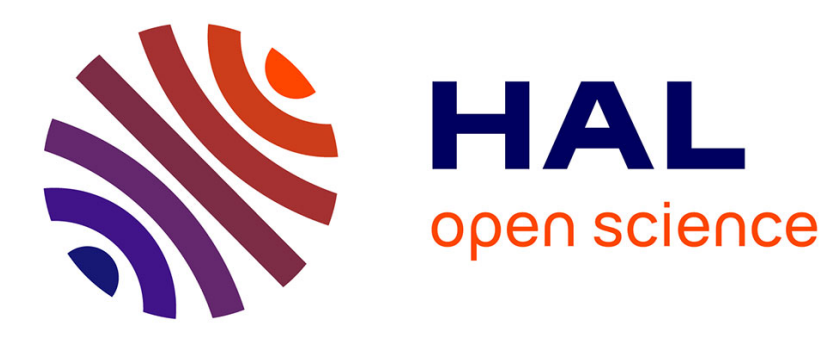

\title{
Does exercise-induced hypoxemia modify lactate influx into erythrocytes and hemorheological parameters in athletes?
}

Philippe Connes, Didier Bouix, Guillaume Py, Corinne Caillaud, Pascale Kippelen, Jean-Frédéric Brun, Alain Varray, Christian Prefaut, Jacques Mercier

\section{To cite this version:}

Philippe Connes, Didier Bouix, Guillaume Py, Corinne Caillaud, Pascale Kippelen, et al.. Does exercise-induced hypoxemia modify lactate influx into erythrocytes and hemorheological parameters in athletes?. Journal of Applied Physiology, 2004, 97 (3), pp.1053-1058. 10.1152/japplphysiol.00993.2003 . hal-01622449

\section{HAL Id: hal-01622449 \\ https://hal.umontpellier.fr/hal-01622449}

Submitted on 22 Mar 2018

HAL is a multi-disciplinary open access archive for the deposit and dissemination of scientific research documents, whether they are published or not. The documents may come from teaching and research institutions in France or abroad, or from public or private research centers.
L'archive ouverte pluridisciplinaire HAL, est destinée au dépôt et à la diffusion de documents scientifiques de niveau recherche, publiés ou non, émanant des établissements d'enseignement et de recherche français ou étrangers, des laboratoires publics ou privés. 


\title{
Does exercise-induced hypoxemia modify lactate influx into erythrocytes and hemorheological parameters in athletes?
}

\author{
Philippe Connes, ${ }^{1}$ Didier Bouix, ${ }^{2}$ Guillaume Py, ${ }^{2}$ Corinne Caillaud, ${ }^{1}$ Pascale Kippelen, ${ }^{2}$ \\ Jean-Frédéric Brun, ${ }^{2,3}$ Alain Varray, ${ }^{1}$ Christian Prefaut, ${ }^{2}$ and Jacques Mercier ${ }^{2,3}$ \\ ${ }^{1}$ EA 2991 “Sport, Performance et Santé," Faculté des Sciences du Sport, Université de Montpellier, \\ 34090 Montpellier; ${ }^{2}$ EA 701 "Physiologie des Interactions," Hôpital Arnaud de Villeneuve, 34295 Montpellier; \\ and ${ }^{3}$ Service Central de Physiologie Clinique, Centre d'Exploration et de Réadaptation des Anomalies \\ du Métabolisme Musculaire, Centre Hospitalier Universitaire Lapeyronie, 34295 Montpellier, France
}

Connes, Philippe, Didier Bouix, Guillaume Py, Corinne Caillaud, Pascale Kippelen, Jean-Frédéric Brun, Alain Varray, Christian Prefaut, and Jacques Mercier. Does exercise-induced hypoxemia modify lactate influx into erythrocytes and hemorheological parameters in athletes? J Appl Physiol 97: 1053-1058, 2004. First published April 30, 2004; 10.1152/japplphysiol.00993.2003.-This study investigated 1 ) red blood cells (RBC) rigidity and 2) lactate influxes into RBCs in endurance-trained athletes with and without exercise-induced hypoxemia (EIH). Nine EIH and six non-EIH subjects performed a submaximal steady-state exercise on a cycloergometer at $60 \%$ of maximal aerobic power for $10 \mathrm{~min}$, followed by $15 \mathrm{~min}$ at $85 \%$ of maximal aerobic power. At rest and at the end of exercise, arterialized blood was sampled for analysis of arterialized pressure in oxygen, and venous blood was drawn for analysis of plasma lactate concentrations and hemorheological parameters. Lactate influxes into RBCs were measured at three labeled $\left[\mathrm{U}_{-}{ }^{14} \mathrm{C}\right]$ lactate concentrations $(1.6,8.1$, and $41 \mathrm{mM})$ on venous blood sampled at rest. The EIH subjects had higher maximal oxygen uptake than non-EIH $(P<0.05)$. Total lactate influx was significantly higher in RBCs from EIH compared with non-EIH subjects at $8.1 \mathrm{mM}(1,498.1 \pm 87.8$ vs. $\left.1,035.9 \pm 114.8 \mathrm{nmol} \cdot \mathrm{ml}^{-1} \cdot \mathrm{min}^{-1} ; P<0.05\right)$ and $41 \mathrm{mM}$ $\left(2,562.0 \pm 145.0\right.$ vs. $\left.1,618.1 \pm 149.4 \mathrm{nmol} \cdot \mathrm{ml}^{-1} \cdot \min ^{-1} ; P<0.01\right)$. Monocarboxylate transporter-1-mediated lactate influx was also higher in EIH at $8.1 \mathrm{mM}(P<0.05)$ and $41 \mathrm{mM}(P<0.01)$. The drop in arterial oxygen partial pressure was negatively correlated with total lactate influx measured at $8.1 \mathrm{mM}(r=-0.82, P<0.05)$ and $41 \mathrm{mM}$ $(r=-0.84, P<0.05)$ in the two groups together. Plasma lactate concentrations and hemorheological data were similar in the two groups at rest and at the end of exercise. The results showed higher monocarboxylate transporter-1-mediated lactate influx in the EIH subjects and suggested that EIH could modify lactate influx into erythrocyte. However, higher lactate influx in EIH subjects was not accompanied by an increase in $\mathrm{RBC}$ rigidity.

monocarboxylate transporter; endurance; lactate metabolism; hypoxemia; hemorheology

TRANSPORT OF LACTATE ACROSS the erythrocyte membrane proceeds by three distinct pathways (9): 1) nonionic diffusion of the undissociated acid; 2) an inorganic anion-exchange system, often referred to as the band 3 system; and 3) a monocarboxylate-specific carrier mechanism (23). Juel et al. (18) recently showed that monocarboxylate transporter-1 (MCT-1) and band 3 expressions were increased with chronic hypoxia exposure, suggesting that these proteins may be upregulated by hypoxia.

Address for reprint requests and other correspondence: J. Mercier, UPRES EA 701 "Physiologie des Interactions," Service Central de Physiologie Hôpital Arnaud de Villeneuve, 34295 Montpellier, France (E-mail: j-mercier @ chu-montpellier.fr).
The functional significance of the hypoxia-induced changes is likely an increase of lactate and $\mathrm{H}^{+}$fluxes from plasma to erythrocyte. During sea-level exercise, some endurance-trained athletes experience arterial hypoxemia [exercise-induced hypoxemia $(\mathrm{EIH})$ ] that can be defined as a decrease in both oxygen arterial partial pressure $\left(\mathrm{Pa}_{\mathrm{O}_{2}}\right)$ and arterial hemoglobin saturation during exercise (8). Miyachi and Katayama (21) have reported repeated episodes of EIH during training sessions when endurance athletes performed very intense exercise, a result suggesting that athletes develop frequent episodes of mild hypoxemia during training. One can thus think that repeated mild hypoxemia stimulus may lead to increased expression or activity of band 3 and MCT-1 proteins on the red blood cell (RBC) membranes. An increase in lactate and $\mathrm{H}^{+}$ fluxes into RBCs during exercise may also alter the deformability of these cells, because lactate uptake by RBCs increases their rigidity (32). These changes in RBC deformability could, in turn, alter blood rheological properties and then participate to EIH. Several studies have suggested that blood viscosity and its determinants, i.e., RBC rigidity and Hct, could be involved in pulmonary diffusion impairment $(6,35)$. First, pulmonary diffusing capacity is widely affected by RBC deformability. When deformability is artificially reduced by chemical treatment, diffusion capacity may decrease by $20 \%$ (4). Second, high blood viscosity or RBC rigidity causes higher mechanical stress on the blood-gas barrier and may result in membrane disruptions. Aguilaniu et al. (1) showed that $6 \mathrm{wk}$ of a polyunsaturated fatty acid (PUFA) diet led to an upward shift in $\mathrm{Pa}_{2}$ in master athletes. PUFA regimens are known to improve RBC deformability and to reduce blood viscosity (15); however, hemorheological measurements were not performed in this study (1).

In the present study, we hypothesized that EIH subjects have 1) a higher capacity for lactate influx in RBCs and 2) a reduced RBC deformability and increased blood viscosity during exercise. To test this hypothesis, we compared RBC lactate influx characteristics at rest in subjects with and without EIH, and we studied the hemorheological profiles at rest and at the end of a submaximal exercise bout.

\section{MATERIALS AND METHODS}

\section{Subjects}

Fifteen male endurance-trained subjects (runners, cyclists, and triathletes) were assigned to one of two groups (EIH or non-EIH) by

\footnotetext{
The costs of publication of this article were defrayed in part by the payment of page charges. The article must therefore be hereby marked "advertisement" in accordance with 18 U.S.C. Section 1734 solely to indicate this fact.
} 
assessing the decrease in oxyhemoglobin saturation [oxyhemoglobin saturation measured by pulse oximetry $\left(\mathrm{Sp}_{\mathrm{O}_{2}}\right)$ ], during a first exercise test. A minimum drop of $3-4 \%$ in $\mathrm{Sp}_{\mathrm{O}_{2}}$ for at least the last three steps of an incremental exercise test is required to conclude that the drop is significant (25). $\Delta \mathrm{Sp}_{\mathrm{O}_{2}}$ was calculated as the difference between $\mathrm{Sp}_{\mathrm{O}_{2}}$ measured at rest and during the last step of the incremental exercise. Group assignment was also confirmed by the decrease in $\mathrm{Pa}_{2}$, i.e., $\Delta \mathrm{Pa}_{\mathrm{O}_{2}}$, measured during a subsequent submaximal test. Nine subjects with EIH were included in the EIH group $(24 \pm 1 \mathrm{yr}, 73.4 \pm 2.2 \mathrm{~kg}$, $180 \pm 3 \mathrm{~cm}, \Delta \mathrm{Pa}_{\mathrm{O}_{2}}=-12.40 \pm 1.17$ Torr, $\Delta \mathrm{Sp}_{\mathrm{O}_{2}}=-4.9 \pm 1.1$ ), and six subjects without EIH were assigned to the non-EIH group $\left(26 \pm 2 \mathrm{yr}, 72.7 \pm 2.2 \mathrm{~kg}, 182 \pm 2 \mathrm{~cm}, \Delta \mathrm{Pa}_{\mathrm{O}_{2}}=-2.50 \pm 1.50\right.$ Torr, $\left.\Delta \mathrm{Sp}_{\mathrm{O}_{2}}=-1.9 \pm 0.4\right)$.

The major exclusion criteria were tobacco use and muscle, joint, and cardiorespiratory diseases.

\section{Experimental Protocol and Procedures}

The local ethics committee approved the study, and each subject gave informed, written consent to participate. The subjects performed two exercise tests on a cycle ergometer (Ergoline type) separated by $1 \mathrm{wk}$. The first one was a progressive and maximal exercise test to determine the maximal cardiorespiratory parameters and $\Delta \mathrm{Sp}_{\mathrm{O}_{2}}$. The second was a submaximal steady-state exercise test. Arterialized blood was sampled at rest and at the end of exercise for analysis of $\mathrm{Pa}_{2}$, and venous blood was sampled at the same times for analysis of plasma lactate concentrations ([Lac]) and hemorheological parameters. Lactate influxes into RBCs were measured on blood sampled at rest.

Exercise tests. The incremental maximal exercise test began with a 3-min warm-up at $60 \mathrm{~W}$. Pedaling speed remained constant $(>70$ $\mathrm{rpm}$ ) throughout testing, and the load was increased by $30 \mathrm{~W}$ every minute until maximal oxygen uptake $\left(\dot{\mathrm{V}}_{2}\right.$ max $)$ was reached. Oxygen uptake $\left(\dot{\mathrm{V}}_{2}\right)$ was considered maximal if at least three of the following criteria were met: 1 ) a respiratory exchange ratio of $>1.10 ; 2$ ) attainment of age-predicted maximal heart rate $[210-(0.65 \times$ age) $\pm 10 \%$ ]; 3) an increase in $\dot{\mathrm{V}}_{2}$ lower than $100 \mathrm{ml}$ with the last increase in work rate; and 4) an inability to maintain the required pedaling frequency $(70 \mathrm{rpm})$, despite maximum effort and verbal encouragement. A 5-min recovery period was then respected with 2 min of pedaling and $3 \mathrm{~min}$ at rest.

One week later, each subject performed a submaximal steady-state exercise based on the maximal intensity determined during the first test. Before exercise, a catheter was inserted into the antecubital vein of the nondominant arm. Venous blood samples were drawn at rest and at the end of exercise (i.e., during the last seconds of the test). After recording of cardiac, ventilatory, and gas exchange data for 5 min at rest, the test began with a 10 -min warm-up at $60 \%$ of $\mathrm{V}_{2}$ max followed by $15 \mathrm{~min}$ at $85 \%$ of $\dot{\mathrm{V}}_{2}$ max. The recovery period consisted of 5 min of pedaling at low intensity.

$\dot{\mathrm{V}}_{2}, \mathrm{CO}_{2}$ output, and ventilation were continuously measured at rest and during exercise and recovery by using a breath-by-breath automated exercise metabolic system (Vmax 229, Sensor Medics). A 12-lead electrocardiogram (Hellige, Marquette Medical Systems) was monitored continuously.

$\mathrm{Sp}_{\mathrm{O}_{2}}$ and $\mathrm{Pa}_{\mathrm{O}_{2}}$. Before measurements, the ear lobe was systematically cleaned with alcohol and rubbed with a vasodilator cream (Finalgon, Boehringer Ingelheim, Barcelona, Spain). During the first exercise test, $\mathrm{Sp}_{\mathrm{O}_{2}}$ was measured by using a noninvasive pulse oximetry method (Satlite Trans, Helsinki, Finland). The ear oximeter has been proven both valid and reliable for measuring significant falls in $\mathrm{Sp}_{\mathrm{O}_{2}}$ during exercise $(24,27)$.

$\mathrm{Pa}_{\mathrm{O}_{2}}$ was determined by using the blood-gas method. Blood was collected at the subject's ear and analyzed immediately (IL Meter 1306, Milan, Italy). We considered a $\mathrm{Pa}_{\mathrm{O}_{2}}$ decrease of at least 8 Torr as significant for EIH, in agreement with the study performed by Anselme et al. (3).
Hemorheology. Seven milliliters of venous blood were collected in Vacutainer tubes (Becton Dickinson) containing EDTA as the anticoagulant for the hemorheological measurements. Hct was measured by the micromethod after blood microcentrifugation. Measurements of blood viscosity and plasma viscosity were performed with a falling ball viscometer (MT 90 Medicatest, Saint Benoit, France) (12). The coefficient of variation for this method ranged from 0.6 to $0.8 \%$ (14). Plasma was obtained via centrifugation at $2,000 \mathrm{~g}$ and $4^{\circ} \mathrm{C}$ for $5 \mathrm{~min}$ (Jouan, Saint Nazaire, France). The index of RBC rigidity (Tk) was calculated according to the equation of Dintenfass (11):

$$
\mu \mathrm{b}=\mu \mathrm{p}[1-(\mathrm{Tk} \cdot \mathrm{Hct})]^{-2.5}
$$

where $\mu \mathrm{b}$ is blood viscosity $(\mathrm{mPa} / \mathrm{s}), \mu \mathrm{p}$ is plasma viscosity $(\mathrm{mPa} / \mathrm{s})$, and Hct is in percent.

Plasma [Lac]. Venous blood $(5 \mathrm{ml})$ was sampled in heparinized tubes (Becton Dickinson). Plasma was obtained via centrifugation at $2,000 \mathrm{~g}$ and $4^{\circ} \mathrm{C}$ for $5 \mathrm{~min}$ in a refrigerated centrifuge (Jouan). Plasma was then isolated and frozen at $-80^{\circ} \mathrm{C}$ until assay. Plasma [Lac] was determined by using an enzymatic method (Roche Diagnostics kit, Mannheim, Germany).

$R B C$ lactate transport. For lactate influx into RBCs, $5 \mathrm{ml}$ of venous blood were collected at rest in heparin tubes (heparin, $0.2 \mathrm{U} / \mathrm{ml}$ ), stored in ice, and prepared before lactate influx measurements.

The techniques for RBC preparation and lactate influx measurement were modified from previously published methods $(30,31)$. The initial Hct (pre-Hct) was determined for all blood samples. One-half $(2.5 \mathrm{ml})$ of each blood sample was transferred to a 50-ml conical tube, depleted of lactate, and washed by using the following procedure. First, the RBCs were isolated by centrifugation at room temperature $\left(25^{\circ} \mathrm{C}, 15 \mathrm{~min}, 2,000 \mathrm{~g}\right)$. Plasma and buffy coat were removed by aspiration. Thirty volumes of chloride buffer $[150 \mathrm{mM} \mathrm{NaCl}$ and 10 $\mathrm{mM}$ sodium tricine, $\mathrm{pH} 8.0$, at $37^{\circ} \mathrm{C}$, osmolality $\sim 315 \mathrm{mosmol} /$ $\mathrm{kgH}_{2} \mathrm{O}$, volume $(\mathrm{ml})=30 \times 2.5 \times$ pre-Hct] were added to the pellet, which was mixed by inversion and incubated in a water bath for 30 $\min$ at $37^{\circ} \mathrm{C}$ to ensure complete removal of endogenous lactate $(10$, $30,31)$. After incubation, the RBCs were sedimented at room temperature $\left(25^{\circ} \mathrm{C}, 10 \mathrm{~min}, 2,000 \mathrm{~g}\right)$, and the supernatant was removed by aspiration. The cell pellet was then washed twice with chloride buffer and suspended in a volume of HEPES buffer $(90 \mathrm{mM} \mathrm{NaCl}, 50 \mathrm{mM}$ HEPES, $\mathrm{pH} 7.4,37^{\circ} \mathrm{C}$, osmolality $\left.\sim 267 \mathrm{mosmol} / \mathrm{kgH}_{2} \mathrm{O}\right)$ equivalent to a $30 \%$ Hct level (packed cell volume) to obtain the stock cell suspension for influx measurements. This suspension was divided into two tubes, each containing $1 \mathrm{ml}$. One of the two tubes contained no lactate transport blockers. The second tube contained $1 \mathrm{mM}$ of $p$-chloromercuribenzenesulfonic acid (PCMBS), which is known to inhibit the monocarboxylate-specific carrier at this concentration (30, 31 ). The tubes were then incubated in a water bath for an additional $30 \mathrm{~min}$ at $37^{\circ} \mathrm{C}$. Part of the stock cell suspension was used for Hct determination (post-Hct).

All samples for lactate influx measurements were run in triplicate. At time $t=0$, a 25- $\mu$ l sample of stock cell suspension was added to a $13 \times 100$-mm test tube containing $75 \mu$ of HEPES influx buffer at $37^{\circ} \mathrm{C}$. The HEPES influx buffer contained L-[U- $\left.{ }^{14} \mathrm{C}\right]$ lactate (sodium salt, specific activity $50 \mu \mathrm{Ci} / \mathrm{mmol}$ ) at three [Lac] values of 2,10 , and $50 \mathrm{mM}$. The HEPES influx buffer was adjusted to $\mathrm{pH}$ 7.4. Because of dilution with the stock cell solution, the actual [Lac] values were 1.6, 8.1 , and $41 \mathrm{mM}$. The cells were exposed to the influx buffer and mixed at $37^{\circ} \mathrm{C}$ for $20 \mathrm{~s}(30,31)$. At that time, $5 \mathrm{ml}$ of an ice-cold stop solution [150 mM NaCl, $10 \mathrm{mM}$ sodium-2-( $N$-morpholino)ethanesulfonic acid, $\mathrm{pH}$ 6.5] were then added to each test tube to stop influx. The sample was spun for $15 \mathrm{~min}$ at $2,000 \mathrm{~g}$ and $4^{\circ} \mathrm{C}$, and the supernatant was removed by aspiration. Control blanks were run in duplicate at the three [Lac] values for both total and MCT-1-mediated lactate influxes, to correct for any residual extracellular radioactivity and for any transmembrane lactate exchange that might have occurred, despite ice-cold stop solution. An additional wash phase was conducted by adding $5 \mathrm{ml}$ of stop solution to each sample. The cells 
were spun again, and the supernatant was removed. The RBC pellet was lysed and deproteinized with $0.5 \mathrm{ml}$ of $4.2 \%$ perchloric acid followed by centrifugation of the sample for $15 \mathrm{~min}(2,000 \mathrm{~g})$ at $4^{\circ} \mathrm{C}$. A $0.4-\mathrm{ml}$ sample was then placed into scintillation vials containing 5 $\mathrm{ml}$ of aqueous counting fluid and counted in a liquid scintillation counter (Tri-Carb Liquid Scintillation Analyzer, model 2200).

Total lactate influx into the RBCs was determined at the three [Lac] values $(1.6,8.1$, and $41 \mathrm{mM})$. For this determination, neither the stock cell solution nor the HEPES influx buffer contained any lactate transport blocker. Influx into PCMBS-treated RBCs was measured at the same three concentrations of lactate. Because PCMBS treatment inhibits the monocarboxylate pathways, influx into the PCMBStreated RBCs was the sum of lactate transport by the band 3 pathway and nonionic diffusion. Therefore, total lactate influx minus influx into the PCMBS-treated cells represents the MCT-1-mediated lactate influx. Control blanks radioactivity was subtracted from the radioactivity measured in samples.

The percentage of contribution from the MCT-1 pathway was calculated by dividing MCT-1-mediated lactate influx by the corresponding total lactate influx. Lactate influx was calculated in nanomoles of lactate per milliliter of cells (erythrocyte) per minute: the 25 $\mu l$ of stock solution were multiplied by its Hct fraction (0.30) to obtain a packed cell volume. Total lactate influxes into RBCs and MCT-1mediated lactate influxes were determined.

\section{Statistical Analysis}

Values are presented as means \pm SE. Subject characteristics and $\dot{\mathrm{V}}_{2}$ max values were compared between groups by using an unpaired Student's $t$-test. Lactate influxes into RBCs were compared with a two-way ANOVA with repeated measures: two groups (EIH subjects and non-EIH subjects) $\times$ three [Lac] values $(1.6,8.1$, and $41 \mathrm{mM})$. The relationships between the drop in $\mathrm{Pa}_{2}\left(\Delta \mathrm{Pa}_{2}\right)$ and the total lactate influx values and between $\dot{\mathrm{V}}_{2}$ max and the total lactate influx values were evaluated for each subject by using a Pearson correlation. Hemorheological parameters and plasma [Lac] were compared by using a two-way ANOVA: two groups $\times$ sample time (at rest or at the end of submaximal exercise). Pairwise contrasts were used when necessary to determine where the significant differences occurred. The level of significance was set at $\alpha=0.05$.

\section{RESULTS}

$\dot{V} \mathrm{O}_{2} \max$

$\dot{\mathrm{VO}}_{2}$ max was significantly higher in the EIH subjects $\left(65.33 \pm 2.09 \mathrm{ml} \cdot \mathrm{kg}^{-1} \cdot \mathrm{min}^{-1}\right)$ compared with the non-EIH subjects $\left(60.27 \pm 0.85 \mathrm{ml} \cdot \mathrm{kg}^{-1} \cdot \mathrm{min}^{-1}\right)(P<0.05)$.

\section{Hemorheological Parameters}

The values of the hemorheological parameters were identical in the two groups at rest (Table 1). During exercise, blood

Table 1. Hemorheological parameters at rest and at the end of submaximal exercise in EIH and non-EIH subjects

\begin{tabular}{|c|c|c|c|c|}
\hline & \multicolumn{2}{|c|}{ EIH Subjects } & \multicolumn{2}{|c|}{ Non-EIH Subjects } \\
\hline & Rest & $\begin{array}{l}\text { End of } \\
\text { exercise }\end{array}$ & Rest & $\begin{array}{l}\text { End of } \\
\text { exercise }\end{array}$ \\
\hline$\mu b, \mathrm{mPa} / \mathrm{s}$ & $3.31 \pm 0.13$ & $3.83 \pm 0.17 *$ & $3.11 \pm 0.11$ & $3.61 \pm 0.15 *$ \\
\hline$\mu \mathrm{p}, \mathrm{mPa} / \mathrm{s}$ & $1.37 \pm 0.01$ & $1.46 \pm 0.01 *$ & $1.33 \pm 0.01$ & $1.44 \pm 0.01 *$ \\
\hline Hct, \% & $42.1 \pm 0.8$ & $45.9 \pm 0.9 *$ & $42.7 \pm 0.4$ & $46.0 \pm 0.9 *$ \\
\hline $\mathrm{Tk}$ & $0.69 \pm 0.02$ & $0.69 \pm 0.01$ & $0.68 \pm 0.01$ & $0.68 \pm 0.01$ \\
\hline
\end{tabular}

Values are means \pm SE. EIH, exercise-induced hypoxemia; $\mu b$, blood viscosity; $\mu$ p, plasma viscosity; Hct, hematocrit; Tk, red blood cell rigidity coefficient. *Significantly different between rest and the end of exercise $(P<$ $0.001)$.

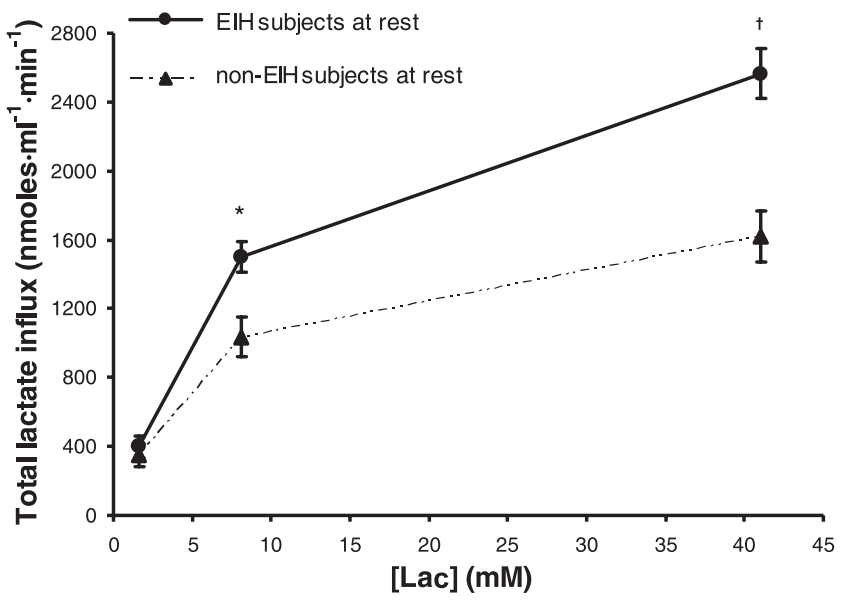

Fig. 1. Total lactate influx into red blood cells (RBCs) from 2 groups at different lactate concentration ([Lac]) values. Values at 8.1 and $41 \mathrm{mM}$ were higher in exercise-induced hypoxemia $(\mathrm{EIH})$ subjects. Values are means $\pm \mathrm{SE}$. $* P<0.05 ; \dagger P<0.001$

viscosity, plasma viscosity, and Hct increased significantly in both groups $(P<0.001)$ and reached similar values. Neither a group nor an exercise effect was observed for RBC rigidity.

\section{Plasma [Lac]}

Plasma [Lac] values were similar for both groups at rest: $2.15 \pm 0.11$ and $2.32 \pm 0.19 \mathrm{mM}$ for $\mathrm{EIH}$ and non-EIH subjects, respectively. At the end of submaximal exercise, the plasma [Lac] was also identical in the two groups: $4.88 \pm 1.12$ and $5.32 \pm 1.34 \mathrm{mM}$ for EIH and non-EIH subjects, respectively.

\section{Lactate Influx into RBCs}

Total lactate influxes into RBCs are illustrated in Fig. 1. At $1.6 \mathrm{mM}$ [Lac], no difference between groups was observed. Total lactate influx was greater in the EIH subjects at $8.1 \mathrm{mM}$ $(P<0.05)$ and $41 \mathrm{mM}[\mathrm{Lac}](P<0.001)$ compared with the other group. MCT-1-mediated lactate influx was higher in the EIH subjects at $8.1 \mathrm{mM}(P<0.05)$ and $41 \mathrm{mM}$ [Lac] $(P<$ 0.001; Fig. 2).

The fractional contribution of MCT-1 to total lactate influx decreased with external [Lac] (Table 2).

Relationships between $\triangle \mathrm{Pa}_{\mathrm{O}_{2}}$ and total lactate influx values. We found no relationship between $\Delta \mathrm{Pa}_{2}$ and total lactate influx measured at $1.6 \mathrm{mM}$ (Fig. 3A). Negative correlations were found between $\Delta \mathrm{Pa}_{\mathrm{O}_{2}}$ and total lactate influx measured at $8.1 \mathrm{mM}(r=-0.82, P<0.05$, Fig. $3 B)$ and between $\Delta \mathrm{Pa}_{\mathrm{O}_{2}}$ and total lactate influx at $41 \mathrm{mM}(r=-0.84, P<0.05$, Fig. 3C).

Relationships between $\dot{V}_{2} \max$ and total lactate influx values. We found no significant correlation between $\dot{\mathrm{V}}_{2}$ max and any of the total lactate influx values.

\section{DISCUSSION}

This study mainly showed that, in the resting condition, total and MCT-1-mediated lactate influxes into RBCs were higher in the EIH subjects at 8.1 and $41 \mathrm{mM}$ [Lac]. In addition, there was a strong correlation between $\Delta \mathrm{Pa}_{2}$ and total lactate influx. The hemorheological profile was the same in the two groups at rest 


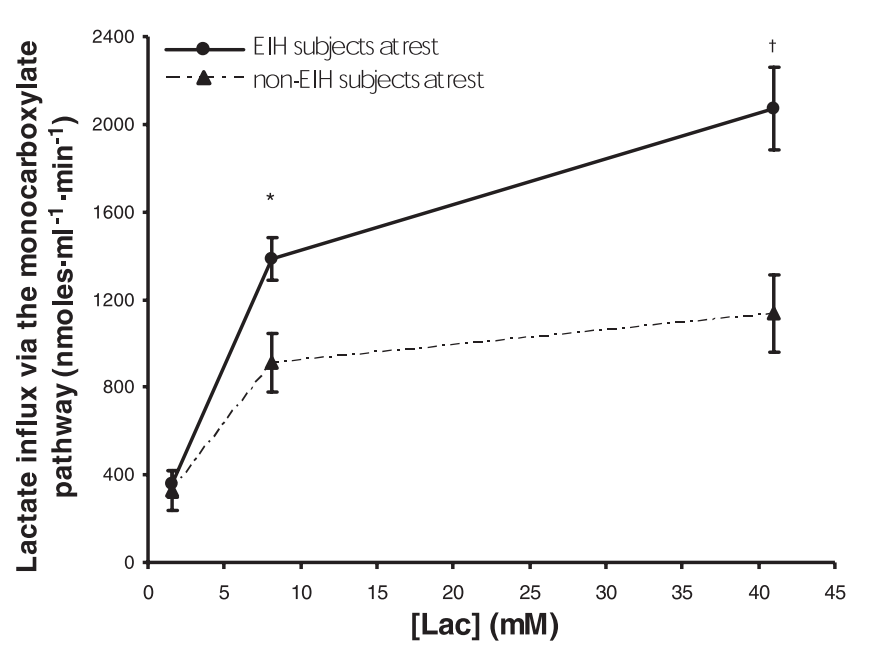

Fig. 2. Lactate influx via the monocarboxylate pathway in RBCs from EIH and non-EIH subjects. Values are means \pm SE. Monocarboxylate transporter-1 (MCT-1)-mediated lactate influx was higher in EIH subjects at $8.1 \mathrm{mM}(* P<$ $0.05)$ and $41 \mathrm{mM}(\dagger P<0.001)$.

and at the end of exercise. These results suggest that EIH can modify lactate fluxes into RBC without any significant change in cell deformability.

\section{Lactate Influx}

We have observed higher total lactate influx into the RBCs from EIH subjects at moderate $(8.1 \mathrm{mM})$ and high [Lac] $(41$ $\mathrm{mM}$ ) than in the other group. We are mindful that the use of another [Lac], as done by Skelton et al. (30), closer to the physiological range would have reinforced our results. From Figs. 1 and 2, we can reasonably think that the use of a [Lac] around $16 \mathrm{mM}$ would have given similar results, i.e., higher total or MCT-1-mediated lactate influx in EIH subjects. The results obtained at the tested concentrations showed in EIH subjects an increased influx via MCT-1, the major pathway of lactate influx into RBCs (30). This could be related to the greater aerobic physical fitness in EIH subject. Indeed, Skelton et al. (31) showed that the lactate influx via MCT-1 was faster in $\mathrm{RBC}$ obtained from animals with high-oxidative capacity (dogs and horses) than from animals with low-oxidative capacity (goats and cattle). However, in the present study, we did not find any significant relationship between $\dot{\mathrm{V}}_{2}$ max and total lactate influx. Lactate uptake by RBCs may, nevertheless, play a role in enhancing physical performance. The accumulation of lactate and hydrogen ions in muscle during exercise may inhibit muscular function and cause fatigue $(13,16)$. HighRBC uptake of these ions could help in establishing a gradient between plasma and interstitial fluid $(9,28)$. Transport of these metabolites away from the exercising muscles into the blood

Table 2. Fractional contribution (\%) of the monocarboxylate transporter-1 pathway to total lactate influx at three lactate concentrations

\begin{tabular}{lccc}
\hline \hline & $1.6 \mathrm{mM}$ & $8.1 \mathrm{mM}$ & $41 \mathrm{mM}$ \\
\hline EIH subjects, \% & $89.7 \pm 0.6$ & $92.5 \pm 1.4$ & $80.8 \pm 4.6$ \\
Non-EIH subjects, \% & $93.8 \pm 3.7$ & $88.0 \pm 0.8$ & $70.2 \pm 3.2$
\end{tabular}

Values are means \pm SE. No significant difference was observed between groups at any concentration. would reduce the potential for muscle acidosis and delay the onset of fatigue.

Recently, Juel et al. (18) found that band 3 and MCT-1 expressions on RBC membranes from humans were increased after 2 and $8 \mathrm{wk}$ of hypoxia exposure. RBC MCT- 1 and band 3 contents increased dramatically $(+330$ and $+150 \%$, respec-

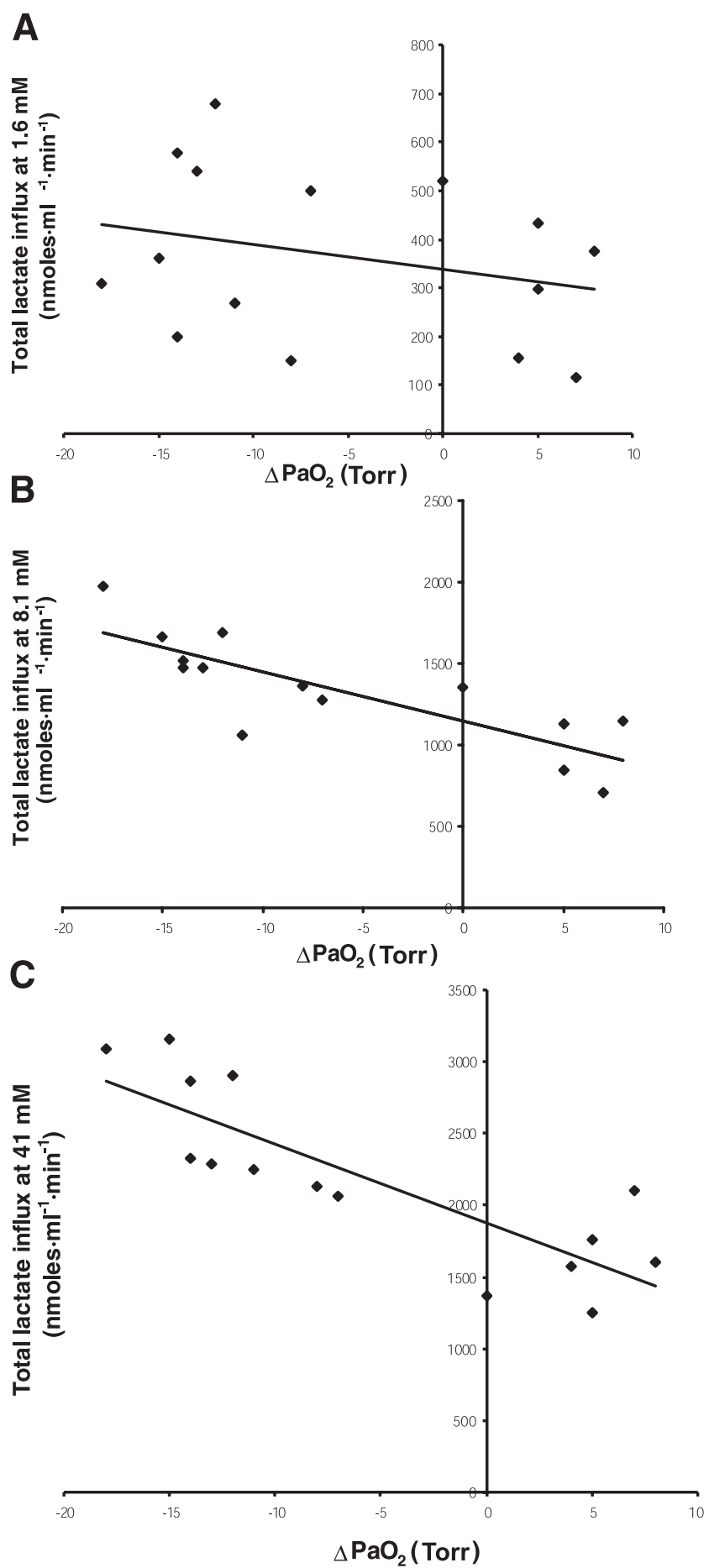

Fig. 3. Relationships between change in oxygen arterial partial pressure $\left(\Delta \mathrm{Pa}_{2}\right)$ and total lactate influx at $1.6 \mathrm{mM}(A ; n=15), 8.1 \mathrm{mM}(B ; n=14)$, and $41 \mathrm{mM}(C ; n=15)$. Significant relationships were found between $\triangle \mathrm{Pa}_{2}$ and lactate influx at $8.1 \mathrm{mM}(r=-0.82, P<0.05)$ and between $\Delta \mathrm{PaO}_{2}$ and lactate influx at $41 \mathrm{mM}(r=-0.84, P<0.05)$. 
tively) after $2 \mathrm{wk}$. These data suggest that the proteins involved in RBC lactate transport can be upregulated by hypoxia. In our study, the subjects exhibiting hypoxemia during exercise had the higher RBC lactate transport activity. These subjects trained regularly, sometimes twice a day, and it is possible that they experienced repeated hypoxemic events that had led to changes in RBC lactate transport activity. We found significant relationships between the drop in $\mathrm{Pa}_{\mathrm{O}_{2}}$ and the total lactate uptake values measured at 8.1 and $41 \mathrm{mM}$, i.e., the two [Lac] values at which differences in total lactate uptake were noted between EIH and non-EIH. Although this finding indicates no causality, this correlation strengthens the argument that the enhanced lactate influx is more related to $\mathrm{EIH}$ than to $\mathrm{V}_{\mathrm{O}_{2}}$ max. Overall, these results suggest that hypoxemia (induced by either exercise or environmental condition) could be a strong stimulus for lactate transport into RBCs by acting on either the expression of the proteins involved or their activity. The underlying physiological mechanism is still unknown but may be related to erythropoietin (Epo) secretion. In a recent study (7), our laboratory showed that 4 wk of treatment with recombinant human Epo led to a significant increase in RBC lactate influx in human subjects. A potential role for Epo in MCT-1 expression might also explain why Juel et al. (18) found an increase in MCT-1 expression on RBC membrane but did not find such a change in muscle samples. Indeed, to our knowledge, there is no Epo receptor in mature human muscular cells.

\section{Hemorheological Measurements}

Blood viscosity was assessed by using a falling ball viscometer, the MT 90 Medicatest. This method was shown to be valid for the assessment of both plasma and blood viscosities in humans $(12,14)$. Moreover, Doffin et al. (12) specifically demonstrated that the MT 90 viscometer measures with a shear rate of $1,000 \mathrm{~s}^{-1}$. Based on the Dintenfass equation, it was thus possible to calculate Tk in our study because this Tk becomes more specific as the shear rate rises (11). Blood viscosity depends on several parameters, including plasma viscosity, Hct, and RBC rigidity $(11,26)$. In our study, the hemorheological parameters involved in blood viscosity regulation had increased to the same value in both groups at the end of exercise, and thus blood viscosity also showed the same increase. This increase in plasma viscosity during exercise could be related to a rise in plasma protein concentration. For example, Vandewalle et al. (34) observed higher plasma concentrations of $\alpha_{1}$-globulins, $\alpha_{2}$-globulins, $\beta$-globulins, and $\gamma$-globulins at the end of a moderate exercise.

Several factors could be responsible for the change in Hct during exercise, including fluid shift, water loss, and RBCs released from the spleen $(17,19,22,33)$, but we did not determine the relative contribution of each factor in this study.

$\mathrm{RBC}$ rigidity did not change with exercise in either group. Usually, $\mathrm{RBC}$ deformability decreases with exercise $(5,29)$. The increased plasma [Lac] and decreased $\mathrm{pH}$ that occur during exercise lead to water loss by RBCs (osmotic process), which, in turn, results in greater rigidity $(20,32)$. In our study, however, the rise in plasma [Lac] during exercise was slight in all subjects, which can explain the lack of RBC rigidity change. The subjects exhibiting EIH had higher RBC lactate transport activity at 8.1 and $41 \mathrm{mM}$ [Lac], but, in vivo, the plasma [Lac] reached lower values during exercise $(<6 \mathrm{mM}$ at the end of exercise). These results could also explain the lack of RBC rigidity difference between the two groups at the end of exercise.

\section{$E I H$}

We investigated blood rheology to clarify its relationship with EIH. Because the measurements were performed at a high-shear rate, we were able to hypothesize about the effects of blood rheological properties in small vessels like the capillaries, even though the blood was drawn from the antecubital vein. At a high-shear rate, blood viscosity depends primarily on erythrocyte rigidity and then on plasma viscosity and Hct, whereas, at a low-shear rate, blood viscosity depends mostly on aggregation properties and Hct.

Previous studies have suggested a potential role of RBC rigidity in pulmonary hemodynamics and pulmonary diffusion limitation. Weiss et al. (35) perfused pony lungs with pentoxifylline-treated RBCs, which are known to be very deformable. They observed a $27 \%$ decrease in filtration pressure, resulting in a $10 \%$ decrease in pulmonary arterial pressure. In master athletes, Aguilaniu et al. $(1,2)$ observed a decrease in EIH severity after a PUFA diet. Because a PUFA diet is known to improve RBC deformability, a potential contribution of blood parameters to EIH genesis cannot be excluded. In our study, it seems that hemorheology did not contribute to EIH during the submaximal exercise performed at $85 \% \quad \dot{\mathrm{V}}_{2}$ max , because no difference between groups was noted for any of the hemorheological parameters. Nevertheless, blood viscosity may contribute to EIH during very intense exercise, i.e., $>90 \% \dot{\mathrm{V}}_{2} \max$, because we observed a greater increase in blood viscosity in the endurance-trained subjects with EIH compared with those without EIH during a progressive and maximal exercise (6).

In conclusion, higher total lactate transport activity and greater MCT-1-mediated lactate influx were found in the RBCs from the EIH subjects, but erythrocyte deformability and blood viscosity were similar in the two groups of endurance-trained subjects. We suggest that the higher lactate influx into RBCs may be more closely related to hypoxemia than to aerobic capacity. Further studies are needed to identify the underlying physiological process.

\section{ACKNOWLEDGMENTS}

The authors express their sincere gratitude to all of the athletes who participated in the present study. We are also grateful to the staffs from the Laboratoire de Physiologie des Interactions (Hopital Arnaud de Villeneuve, Montpellier, France) and Service de Médecine Nucléaire (Hopital Lapeyronie, Montpellier, France) for their vital contribution. We thank C. Carmeni for help in writing the English manuscript.

\section{REFERENCES}

1. Aguilaniu B, Flore P, Page E, Maitre J, Lacour JR, and Perrault H. Effects of indomethacin and polyunsaturated fatty acid diet on exerciseinduced hypoxaemia in master athletes. Eur J Appl Physiol 77: 81-88, 1998.

2. Aguilaniu B, Flore P, Perrault H, Page JE, Payan E, and Lacour JR. Exercise-induced hypoxaemia in master athletes: effects of a polyunsaturated fatty acid diet. Eur J Appl Physiol 72: 44-50, 1995.

3. Anselme F, Caillaud C, Couret I, Rossi M, and Prefaut C. Histamine and exercise-induced hypoxemia in highly trained athletes. J Appl Physiol 76: 127-132, 1994.

4. Betticher DC, Reinhart WH, and Geiser J. Effect of RBC shape and deformability on pulmonary $\mathrm{O}_{2}$ diffusing capacity and resistance to flow in rabbit lungs. J Appl Physiol 78: 778-783, 1995. 
5. Bouix D, Peyreigne C, Raynaud E, Monnier JF, Micallef JP, and Brun JF. Relationships among body composition, hemorheology and exercise performance in rugby men. Clin Hemorheol Microcirc 19: 245-254, 1998.

6. Connes P, Bouix D, Durand F, Kippelen P, Mercier J, Prefaut C, Brun $\mathbf{J F}$, and Caillaud C. Is hemoglobin desaturation related to blood viscosity in athletes during exercise? Int J Sports Med In press.

7. Connes P, Caillaud CF, Mercier J, Bouix D, and Casties JF. Injections of recombinant human erythropoietin increases lactate influx into erythrocytes. J Appl Physiol 97: 326-332, 2004. First published February 13, 2004 ; 10.1152/japplphysiol.00715.2003.

8. Dempsey JA, Hanson PG, and Henderson KS. Exercise-induced arteria hypoxaemia in healthy human subjects at sea level. $J$ Physiol 355: $161-175,1984$.

9. Deuticke B. Monocarboxylate transport in erythrocytes. J Membr Biol 70: 89-103, 1982

10. Deuticke B. Monocarboxylate transport in red blood cells: kinetics and chemical modification. Methods Enzymol 173: 300-329, 1989.

11. Dintenfass L. Red cell rigidity, Tk, and filtration. Clin Hemorheol 5: 241-244, 1985.

12. Doffin J, Perrault R, and Garnaud G. Blood viscosity measurements in both extensional and shear flow by a falling ball viscometer. Biorheology 1, Suppl: 89-93, 1984.

13. Fitts RH. Cellular mechanisms of muscle fatigue. Physiol Rev 74: 49-94, 1994

14. Fons C, Brun JF, Supparo C, Mallard C, Bardet L, and Orsetti A. Evaluation of blood viscosity at high shear rate with a falling ball viscometer. Clin Hemorheol 13: 651-659, 1993.

15. Guezennec CY, Nadaud JF, Satabin P, Leger F, and Lafargue $P$. Influence of polyunsaturated fatty acid diet on the hemorrheological response to physical exercise in hypoxia. Int J Sports Med 10: 286-291, 1989.

16. Hogan MC, Gladden LB, Kurdak SS, and Poole DC. Increased [lactate] in working dog muscle reduces tension development independent of $\mathrm{pH}$. Med Sci Sports Exerc 27: 371-377, 1995.

17. Isbister JP. Physiology and pathophysiology of blood volume regulation Transfusion 18: 409-423, 1997.

18. Juel C, Lundby C, Sander M, Calbet JA, and Hall G. Human skeleta muscle and erythrocyte proteins involved in acid-base homeostasis: adaptations to chronic hypoxia. J Physiol 548: 639-648, 2003.

19. Laub M, Hvid-Jacobsen K, Hovind P, Kanstrup IL, Christensen NJ, and Nielsen SL. Spleen emptying and venous hematocrit in humans during exercise. J Appl Physiol 74: 1024-1026, 1993.

20. Lipovac V, Gavella M, Turk Z, and Skrabalo Z. Influence of lactate on the insulin action on red blood cell filterability. Clin Hemorheol 5: 421-428, 1985 .
21. Miyachi M and Katayama K. Effects of maximal interval training on arterial oxygen desaturation and ventilation during heavy exercise. Jpn J Physiol 49: 401-407, 1999.

22. Ploutz-Snyder LL, Convertino VA, and Dudley GA. Resistance exercise-induced fluid shifts: change in active muscle size and plasma volume. Am J Physiol Regul Integr Comp Physiol 269: R536-R543, 1995.

23. Poole RC and Halestrap AP. Transport of lactate and other monocarboxylates across mammalian plasma membranes. Am J Physiol Cell Physiol 264: C761-C782, 1993.

24. Poppius $\mathbf{H}$ and Viljanen AA. A new ear oximeter for assessment of exercise-induced arterial desaturation in patients with pulmonary diseases. Scand J Respir Dis 58: 279-283, 1977.

25. Prefaut C, Durand F, Mucci P, and Caillaud C. Exercise-induced arterial hypoxaemia in athletes: a review. Sports Med 30: 47-61, 2000.

26. Quemada D. Rheology of concentrated disperse systems. II. A model of non newtonian shear viscosity in steady flows. Rheol Acta 17: 632-642, 1978.

27. Rebuck AS, Chapman KR, and D'Urzo A. The accuracy and response characteristics of a simplified ear oximeter. Chest 83: 860-864, 1983.

28. Roth DA. The sarcolemmal lactate transporter: transmembrane determinants of lactate flux. Med Sci Sports Exerc 23: 925-934, 1991.

29. Signorelli S, Tornetta D, Ferrara M, Interlandi S, Lo Duca S, Monaco S, Cottini E, and Andreozzi GM. [Hemorheological changes during exercise]. Ric Clin Lab 15, Suppl 1: 163-167, 1985.

30. Skelton MS, Kremer DE, Smith EW, and Gladden LB. Lactate influx into red blood cells from trained and untrained human subjects. $\mathrm{Med} \mathrm{Sci}$ Sports Exerc 30: 536-542, 1998.

31. Skelton MS, Kremer DE, Smith EW, and Gladden LB. Lactate influx into red blood cells of athletic and nonathletic species. Am J Physiol Regul Integr Comp Physiol 268: R1121-R1128, 1995.

32. Smith JA, Telford RD, Kolbuch-Braddon M, and Weidemann MJ. Lactate $/ \mathrm{H}^{+}$uptake by red blood cells during exercise alters their physical properties. Eur J Appl Physiol 75: 54-61, 1997.

33. Stephenson LA and Kolka MA. Plasma volume during heat stress and exercise in women. Eur J Appl Physiol 57: 373-381, 1988.

34. Vandewalle H, Lacombe C, Lelievre JC, and Poirot C. Blood viscosity after a 1-h submaximal exercise with and without drinking. Int J Sports Med 9: 104-107, 1988.

35. Weiss DJ, Geor RJ, and Burger K. Effects of pentoxifylline on hemorheologic alterations induced by incremental treadmill exercise in thoroughbreds. Am J Vet Res 57: 1364-1368, 1996. 